\title{
Relationship of Montessori Approach with Interior Spaces in Preschools and Physical Set-up
}

\author{
Montessori Yaklaşımının Anaokulu Iç Mekanları ve Fiziksel Oluşumu ile ilișkisi
}

\author{
Meryem YALÇIN
}

Montessori education gathers around two purposes: biological and social purposes. Helping natural development of an individual is targeted in the biological part, and preparation of an individual for the environment is targeted in the social part (Montessori, 1947). Fundamental element of Montessori approach is to form the space. Although there are plenty of studies present in the literature on this subject, it was noted that studies on interior spaces, with which people have quite intensive and higher level of relationship, turned out to be very few. Thus, in this study, in the context of findings determined by conceptual components affecting physical characteristics in the formation of interior spaces, particularly in kindergartens applying Montessori education model, which has become widespread in preschool educational institutions in Turkey during the past ten years; For this reason five (all) institutions in Ankara were selected as the area of study with more than one data collection technique, and survey with quantitative approach, and document investigation with qualitative approach and monitoring (mechanical) techniques were used. In the applied study, characteristics making up the interior space in preschool educational institutions were studied in the content of the titles of Properties of Interiors, General Spatial Standards of Day Care Centre, Atmospheric Properties Floor, Wall, Furnishings etc...), Furniture and Equipment, and the sample interior- space forming model for design setting was suggested.

Keywords: Conceptual-Physical Relationship; interior design settings; Montessori Preschools.

ÖZ

Montessori eğitimi iki amaç etrafında toplanır: biyolojik ve sosyal amaçlar. Bir bireyin doğal gelişimine yardımcı olmak biyolojik yönünü hedef alırken ve çevre için bireyin hazırlanması toplumsal yönünü hedefler (Montessori, 1947). Montessori yaklaşımının temel unsuru mekanı oluşturmaktır. Bu konuda literatürde çok sayıda çalışma olmasına rağmen, insanların oldukça yoğun ve yüksek düzeyde ilişkilere sahip olduğu iç mekanlarla ilgili çalışmaların çok az olduğu ortaya çıkmıştır. Bu nedenle, bu çalışmada, özellikle son on yılda Türkiye'de okul öncesi eğitim kurumlarında yaygınlaşan Montessori eğitim modelini uygulayan anaokullarında iç mekan oluşumunda fiziksel özellikleri etkileyen kavramsal bileşenler tarafından belirlenen bulgular bağlamında; Ankara'da beş (tüm) kurum birden fazla veri toplama tekniği ile çalışma alanı olarak seçilmiş, niceliksel yaklaşımla anket, nitel yaklaşım ile izleme (mekanik) teknikleriyle belge araştırması kullanılmıştır. Uygulamalı çalışmada, iç Mekanların Özellikleri, Anaokulunun Genel Mekansal Standartları, Atmosferik Zemin Kat, Duvar, Mobilyalar vb. Başlıkları kapsamında, okul öncesi eğitim kurumlarındaki iç mekanı oluşturan özellikler incelenmiştir. Ayrıca, Mobilya, Ekipman ve tasarım ortamı için örnek iç mekan oluşturma modeli önerilmiştir.

Anahtar sözcükler: Kavramsal-fiziksel ilişkiler; iç mekan tasarımı; Montessori Anaokulları.

Department of Interior Architecture and Environmental Design, TOBB University of Economics and Technology, Ankara 


\section{Introduction}

As presented in the latest studies in Experimental Psychology, it has been observed that particularly during early childhood, every stimuli of the physical and social environment becomes a discovery and learning experience which forms the fundamentals of intellectual, physical, social, emotional and perceptual development (Day \& Midbjer, 2007; Gür \& Zorlu, 2002; Dudek, 2000 and 2001; Moore, 2002; Weinstein \& David, 1987). Besides, Maria Montessori states that when an environment equipped with concrete experiences and prepared with well designed materials, a high level of learning will be achieved. Fundamental element of Montessori approach is to form the space. Since, physical freedom of children can be achieved with vital tools which provide a free environment to express and develop themselves. (Wilbrandt, 2006; Demiriz at al., 2003; Dyck, 2002). For her a creative activity cannot be formed on its own readily. It is a constant method, taking a life style form, by means of encouragement and guidance. (Yin, 2003; Gür at al., 2002; Şener, 2001). However, children develop affective relationships in various contexts with their environment deeply and in layered functionalities. These relationships provide not only emotional and psychological affordances, but also cognitive and social affordances which satisfy sense of place, integrate and enable engagement of children. For Montessori approach the owner of everything in the space is children. Therefore, it will be beneficial for the development of the matter that the space sensation of preschool children is investigated in more detail. In this stage, the significant questions are as follows; 'How do children perceive their physical environment' and 'How do these environmental (spatial) teachings develop in preschool education' (Bozdayı, 1988). In case the space perception, which is effective in children's development to this extend.

Philosophers and psychiatrists have discussed for centuries whether the nature of the spatial stems from the concepts based on experience stemming from human perception of the space or originating from an inner characteristic existing in the consciousness from birth. As a result, these discussions, which form the substructure of experimental psychology, have revealed that real effective factors in the development of spatial concept are due to information formed owing to intellectual development of the children (Çanakçıoğlu, 2012).

In this respect, perception theories through built environment are investigated under the two titles, empirical and nativist (Day \& Midbjer, 2007). Perception theories studied in the context of empirical theories have been developed by the works of experimenting philosophers such as Locke, Berkeley and Hume, defending that the percep- tion is coded in human mind as a result of experiences gained in the environment which the person is interacting with. Nativist theory, on the other hand, focuses on the fact that perceptional experience formed by the surrounding of the person originates from a series of inner thoughts and information, thought to exist in their mind from birth. Cognition psychologists, studying under this conceptual framework, investigate this perceptional process within a mechanism process as disaggregation, integration, evaluation and coding to mental scheme of information piles (Çanakçıŏlu, 2012; Flores, 2004; Poyraz at al., 2001). Interior spaces are environments where space perception of individuals is the most intense and which direct the individuals. In this context, the significance of the study is emphasized once again.

On the other hand, some researchers, and especially Rapoport (2000), defend that cultural component is quite effective in the formation of environmental perception. For him certain behavior patterns displayed by societies, which have a common culture, influence their environmental arrangements and cause their environmental perceptions to differentiate from those of other societies. Rapoport (2000) explains the perception as being a part of socio-cultural norms and a natural result of them and argues that multi-emotional perception of humans are affected by variables such as visual, auditory, tactile, walking, air movements and heat, and defends that these factors, which show differences in various cultures, create differences on perception mechanisms of humans as well (Flores, 2004). Although Montessori educational model contains physical characteristics, accepted universally according to children development, besides the coinciding of characteristics of these spaces with educational activities, they are under the influence of many factors such as child psychology, development, identity, skills, the society they are in, and socio-economic group which varies between cultures. So, within this context Ankara as an area of study have been examined to provide subtle data and concretize point of origin. However, before this, the study evaluates Turkey case to provide background information as cultural sample in the Montessori preschool education model and its formation in the interior spatial set-up in specific local area (Figure 1).

\section{Development of Montessori Method in Turkey and it's Spatial Formation}

When its development in Turkey is investigated, Guler Yucel emerges with her studies of Montessori Method during the 60 's. Yucel took part in the organization of the treatment department where Montessori method is applied in Istanbul University Capa Children's Psychiatry Department during the 70 's, and translated "The Secret of 

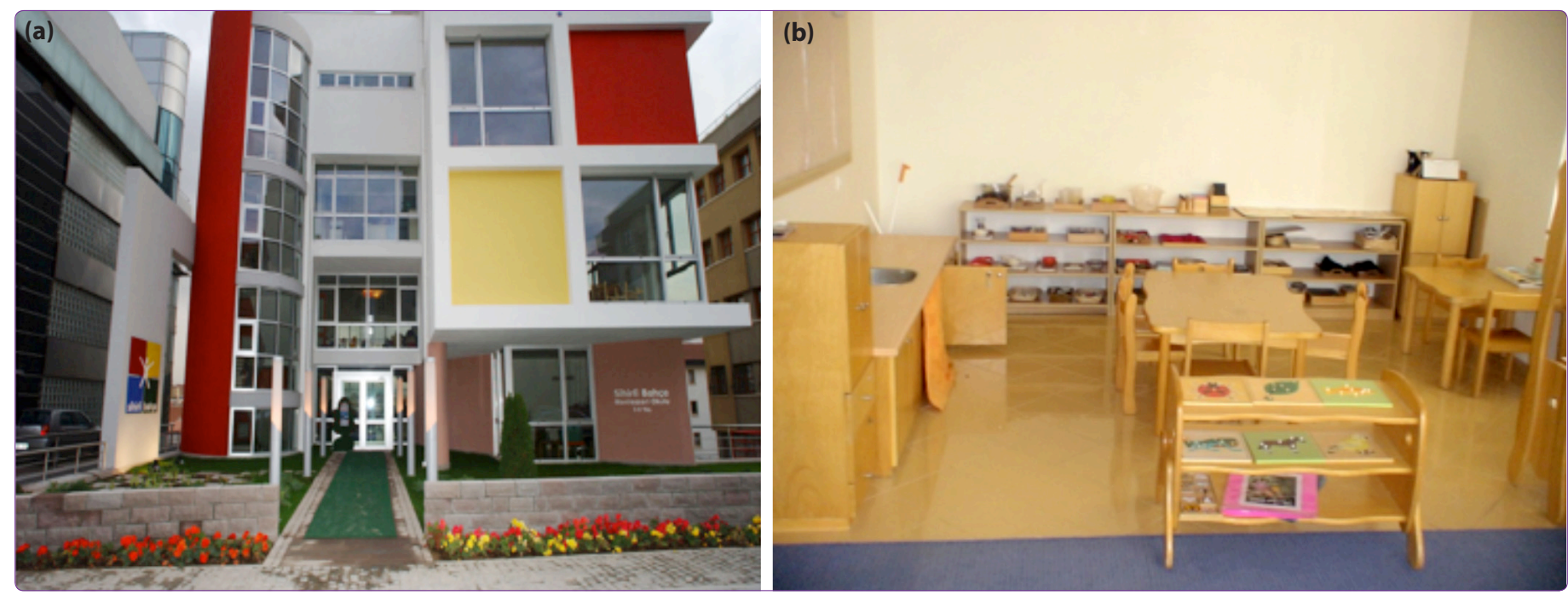

Figure 1. (a, b) Exterior and Interior View of Sihirli Bahce Montessori Preschool (Note; An example of Montessori approach on the positive spatial formation of the Sihirli Bahce Preschool from Ankara).

Childhood", the only book about Montessori translated to Turkish. Application of the method in Turkey on mentally retarded children has started in the 70's and continued until the end of the 90's. The reasons Montessori Method did not widespread in Turkey are disinterest in alternative education in Turkey and reserve for Montessori Method and lack of scientific studies conducted in this subject (Korkmaz, 2006).

When literature is examined, the following studies have been encountered about Montessori education. According to Temel (2005), among new approaches in preschool education, there is Reggio Emilia approach, and besides Open Education approach, there is Montessori approach. In Akyol's and Oguz's study of the Ministry of National Education in 2002, about the similarities between the preschool program for 36-72 month old children and Montessori approach; 2002 preschool education program for 36-72 month old children was formed by considering feedbacks coming from experts and practitioners on the program applied. Since 1994 and by considering changing needs of the society and approaches for modern children education, it was defended that Montessori approach should be included in approaches directed for modern children education. Montessori education model has been widespread in Turkey during the past 10 years and has been currently implemented in more than 80 kindergartens (M.E.B, 2013).

However, although the education system in Turkey is defined as "children centered", actually it is not the case. There is no "curriculum" based education system which is mandatory with a standard curriculum applied in the entire country for a certain period of time. In this case, application of "children based" education is very hard and as a matter of fact it is not able to be applied (Yaran, 2009; Temel, 2005). Spatial necessity is not perceived along with this. So, interior space formation has been determined since there are socio-cultural, economic, physical, institutional, etc. effects in approximately 30 preschool educational institutions investigated in the study context and among these, in Montessori Model applying preschool education institutions. For instance, expensive fields in terms of situation and hard climatic conditions bring limitations in the green field. Preschools and kindergartens are either the lower floor of an apartment building or they are multistorey buildings.

Overlap of the education system in preschool classes and spatial set up is the targeted main subject. Various educational activities should be applicable and their spatial equivalent should be changeable and design elements should be improvable and functional solutions should be created. The main elements of the space design are preschool spatial arrangement directed for the space design of the educational decisions aiming child development, space groups, renational space arrangement, interior space characteristics and furniture-equipment characteristics. Conceptual contents of these elements (education, institutional identity, culture, etc.) should be considered in the physical space set up. Physical opening of conceptual elements, that is universality, effective learning, adaptation to the current environment, children based education, individuality and independence of children, feeding of permanent curiosity in a Montessori kindergarten are set up and studied below. Based on this awareness, interior space design model of "Montessori kindergarten" formed in the study content is as follows; Figure 2. 


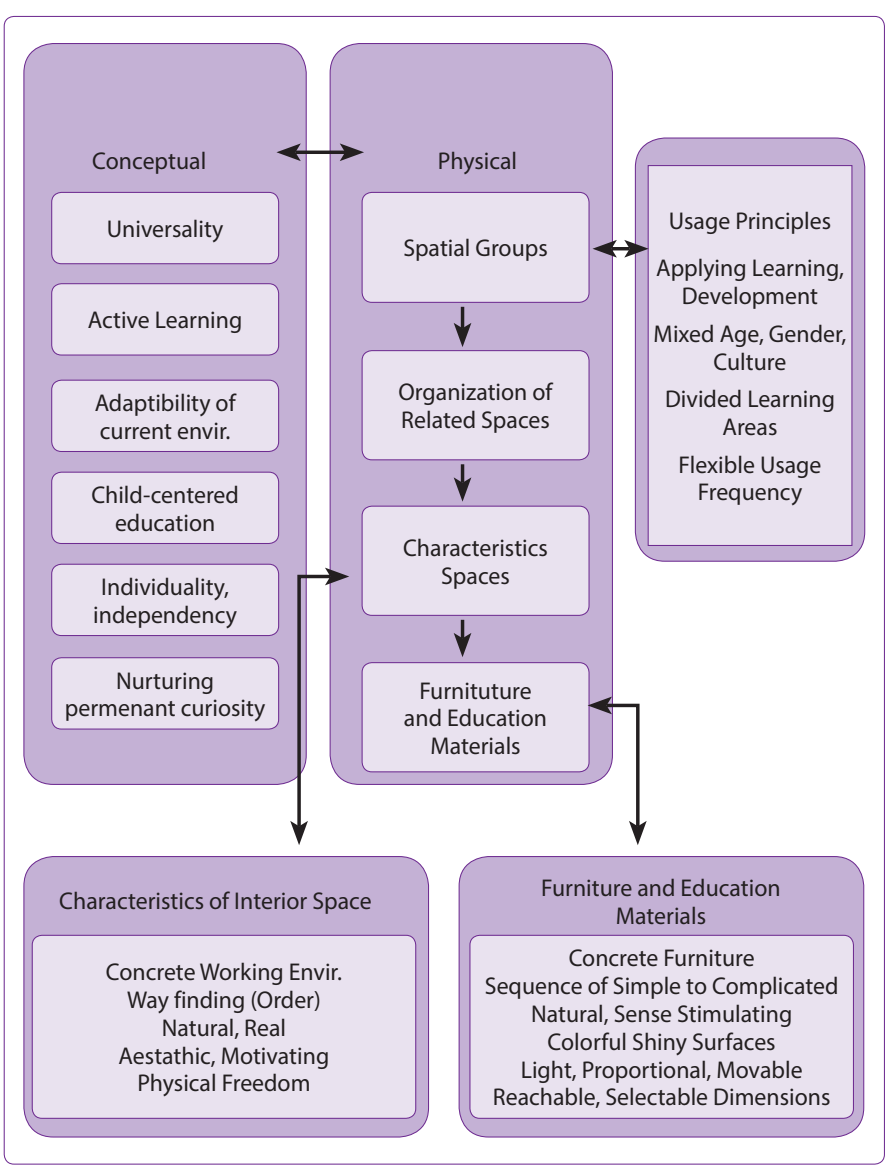

Figure 2. Model of Preschool Interior Space Set-Up within the Montessori Method. Note: Conceptual-physical relationships in preschool educational space formation in Montessori Method and its subcomponents.

\section{Model of Preschool Interior Space Set-Up within the Montessori Method}

Note: Conceptual-physical relationships in preschool educational space formation in Montessori Method and its subcomponents.

This design model has characteristics of a suggestion involving Montessori philosophy, and harmonizing and summarizing interior spatial set up. The generated model contains concepts such as children based education, effective learning, adaptation to the current environment, independence and feeding of permanent curiosity, which are desired to be included in children's development thorough space in Montessori Model in preschool education. Physical reflections of these are realized owing to correct set up of space groups, their characteristics and relationships and convey of the potentials of interior space characteristics and educational materials among furniture to children.

Properties of Interiors Space; Tangible study environment, direction finding (arrangement), real life units, naturalness, aesthetics and motivation, accessibility, etc.

General Spatial Standards of Day Care Center: Learning and development by practicing, mixed ages, gender and culture, persistence in the space, flexible usage frequency.

Atmospheric Properties Floor, Wall, Furnishings etc...): Naturality, aesthetics, reality

"...what is above all essential is that it should be 'artistically beautiful.' In this case beauty is not produced by superfluity or luxury, but by grace and harmony of line and color, combined with that absolute simplicity necessitated by the lightness of the furniture." (Montessori, 1964).

Furniture and Education Equipment: Safety, reality, sequencing from easy to hard, aesthetics, lightness, ratio, and educational, flexible and changeable interior space characteristics enable Montessori Program to be actualized in preschool educational institutions.

This study, within the formed conceptual frame content, is a design model of conditions brought by modern culture suggested to conceptual-physical relations and sub components in interior space formation of preschool educational centers, applying Montessori educational model.

\section{Methodology}

Sub components of the study have been formed by findings and the generated model, determined by conceptual analysis of conceptual components influencing physical space, which is defended to be realized in preschool interior space set up. Based on this awareness, findings, purpose, scope and content of the conducted study has been covered in this section.

\section{Purpose of the Study}

Positive effects of Montessori education philosophy on physical space characteristics are to bring a different point of view to cultural development in addition to universal characteristics in Interior Space formation, and the place of parents, educators and institution owners in centers. They use Montessori educational tools and/or apply Montessori educational model within this process, and investigating the formation of observation and opinions in interior space, providing resources for the investigation of this method in the application in Turkey and the results in physical space. Thus, it is to add new ones to studies, which are rather few and which investigate preschool institutions applying Montessori educational model.

\section{Sample}

It was determined that Montessori education model applying preschool institutions among approximately 30 of them investigated in Ankara have more qualified physical characteristics, and parents who prefer these institutions consider specifically interior spatial characteristics and educational materials. As a field study, five (all) Montessori preschool educational institutions in Ankara, namely Sihirlibahce, Ilk Iz, Binbir Cicek, Karabalik and Jale Tezer Montessori Kindergartens were examined. A perspective 
was brought to the formation of the purpose, content and scope of Montessori educational philosophy within the reflection style of socio-cultural parameters on the formation of interior space, furniture-equipment and design set up in these institutions.

\section{Problem Sentence}

How is the Interior Spatial set up formed and cultural variables affected in preschool education of Montessori Method?

\section{Other Problems}

1. How is the investigated Montessori Method's built environmental conditions formed in the Interior space?

2. What are the differences and reasons in the built environmental conditions formed in the investigated Montessori preschool educational institutions?

3. What are the spatial design approaches of respondents (institution owners, administrators, educators and parents) from the studied Montessori preschool?

\section{Assumptions}

1. Institution owners, administrators, educators and parents are aware of the significance of spatial characteristics for the development of children in Montessori preschool educational institutions that were investigated. These characteristics were regarded in the spatial formation of the institutions and in their selection.

2. Spatial differences in Montessori preschool educational institutions that were investigated originate from socio-cultural conditions.

\section{Data Collection Tools}

Five Montessori educational model-applying preschool institutions in Ankara field study area were selected, and more than one data collection techniques, namely, survey with quantitative approach, document study with qualitative approach and monitoring (mechanical) techniques were used. Analysis of the data obtained as a result the survey application was conducted with $p$ and $\alpha$ values, obtained by ANOVA technique of SPSS program.

\section{Data Collection Method}

1. Conceptual sub component of the study was formed with the literature survey of preschool education and its models, children-space relationship and Montessori education and environmental characteristics, and with the data obtained by the investigation of Montessori kindergartens in this country and the world.

2. Five institutions applying Montessori educational model among approximately 30 preschool institutions in Ankara were analyzed in place, and inter- views were conducted with institution personnel and parents with observation and investigation method, and data results obtained from observations and opinions were evaluated.

3. The survey, which questions the titles making up the interior space of the mentioned institutions in the applied study, which are questions the sub components defining these titles, was applied to the educational institution owners, administrators, educators and parents.

\section{Findings and Discussions}

The study was carried out in five (all) preschool educational institutions applying Montessori educational model during 2011-2012 academic year in Ankara; the research was conducted with the participation of 87 individuals, namely parents, administrators, teachers and institution owners, having influence in the formation of preschool institutions (Table 1).

\section{Demographic Distribution of the Participants}

The survey was applied to 87 people. It is seen at the table 1 based on the demographic information about them that average age of the participants was 32.2 with 6.8 of standard deviation. 62 of these were women and 25 were men. $85 \%$ of the participants had a university education or higher education (Table 2).

ANOVA Results of Four Main Headings of Interior Space

Table 1. Demographic Distribution of the Participants

\begin{tabular}{|c|c|c|c|c|c|}
\hline & $\mathbf{N}$ & & M & & SD \\
\hline Age & 87 & & 32.2 & & 6.8 \\
\hline Education & 84 & & 3.1 & & 0.85 \\
\hline \multirow[t]{2}{*}{ Gender } & & Female & & Male & \\
\hline & & 62 & & 25 & \\
\hline
\end{tabular}

Table 2. ANOVA Results of Four Main Headings of Interior Space Characteristics of Preschool Education Centers Applying Montessori Education model

\begin{tabular}{lcccc}
\hline & N & M & SD & P \\
\hline $\begin{array}{l}\text { Properties of } \\
\text { Interior Spaces }\end{array}$ & 87 & 15.9 & 2.3 & 0.000 \\
$\begin{array}{l}\text { General Spatial } \\
\text { Standards }\end{array}$ & 79 & 25.1 & 2.4 & 0.146 \\
$\begin{array}{l}\text { Atmospheric } \\
\text { Properties }\end{array}$ & 81 & 16.4 & 2.0 & 0.984 \\
$\begin{array}{l}\text { Properties of } \\
\text { Furnishings }\end{array}$ & 86 & 17.3 & 2.0 & 0.403 \\
\hline
\end{tabular}


Table 3. Evaluation of the Approach for Interior Space of Five Preschool Institutions Applying Montessori Education Method

\begin{tabular}{|c|c|c|c|c|c|}
\hline \multicolumn{6}{|c|}{ Properties of interiors } \\
\hline & $\begin{array}{c}\text { Visual } \\
\text { Attractiveness }\end{array}$ & $\begin{array}{l}\text { Developmentslly } \\
\text { Encouraging }\end{array}$ & $\begin{array}{l}\text { Physical } \\
\text { Comfort }\end{array}$ & $\begin{array}{l}\text { Stimulating } \\
\text { Creativity }\end{array}$ & $\begin{array}{l}\text { Pure and } \\
\text { Natural }\end{array}$ \\
\hline M & 2.2 & 3.9 & 3.7 & 3.4 & 3.2 \\
\hline SD & 0.8 & 0.3 & 0.6 & 0.8 & 0.7 \\
\hline \multicolumn{6}{|c|}{ General Pysical Standarts } \\
\hline & $\begin{array}{c}\text { Amount of Area } \\
\text { per child }\end{array}$ & $\begin{array}{c}\text { Teacher/children } \\
\text { Proportion }\end{array}$ & $\begin{array}{c}\text { Variety of } \\
\text { activity areas }\end{array}$ & Material Quality & Functionality \\
\hline M & 3.6 & 3.8 & 3.7 & 3.6 & 3.7 \\
\hline SD & 0.8 & 0.4 & 0.5 & 0.6 & 0.5 \\
\hline \multicolumn{6}{|c|}{ Atmospheric Objectives (Floor, Wall, Furnishings etc...) } \\
\hline & $\begin{array}{l}\text { Flashy and } \\
\text { Figured }\end{array}$ & Natural Colours & $\begin{array}{c}\text { Natural/Healthy } \\
\text { Material }\end{array}$ & $\begin{array}{c}\text { Various Instructive } \\
\text { Texture }\end{array}$ & $\begin{array}{c}\text { Bright and } \\
\text { Sunny Spaces }\end{array}$ \\
\hline M & 2.7 & 3.0 & 3.7 & 3.4 & 3.7 \\
\hline SD & 0.9 & 0.6 & 0.5 & 0.6 & 0.5 \\
\hline \multicolumn{6}{|c|}{ Properties of Furniture } \\
\hline & $\begin{array}{l}\text { Natural } \\
\text { Materials }\end{array}$ & $\begin{array}{l}\text { Proportion and } \\
\text { Ergonomic }\end{array}$ & $\begin{array}{c}\text { Flashy } \\
\text { Appearance }\end{array}$ & $\begin{array}{l}\text { Mobility, } \\
\text { Flexibility }\end{array}$ & $\begin{array}{c}\text { Multi } \\
\text { Functionality }\end{array}$ \\
\hline M & 3.7 & 3.6 & 3.0 & 3.4 & 3.6 \\
\hline SD & 0.5 & 0.5 & 0.9 & 0.6 & 0.6 \\
\hline
\end{tabular}

Characteristics of Preschool Education Centers Applying Montessori Education model.

Significance level of the mentioned characteristics is $\alpha=0.05$. When $p$ values, obtained as a result of ANOVA conducted in the Table 2, are studied, it is seen that all of them are larger than $\alpha=0.05$ value. In this case, $\mathrm{HO}$ absence hypothesis established for the content of the above mentioned four main titles cannot be rejected. In other words, these four characteristics do not differentiate for all institutions separately. In other saying, these institutions display rather similar characteristics in terms of these four main titles. Therefore hypothesis of the study has been supported. That is to say, sharing of similar socio-cultural parameters and displaying harmonized results of the educational model in these institutions means that expectations and needs of the persons being effective in the space formation in these institutions are also similar. In other words, it is seen that, based on the information gathered while forming the sub structure of the study, and based on the observations made in the institutions and interviews conducted with institution owners, spatial approaches of the parents selecting these institutions are proper and conscious applications and selections in terms of children's development. This is gathered from the questions directed under sub titles, which are collected under four main titles, and from the standard deviations (Table 3).
Evaluation of the Approach for Interior Space of Five Preschool Institutions Applying Montessori Education Method

When some of the findings, which were determined according to some statistical values of the characteristics of the five preschool education centers applying Montessori education model in Ankara, are mentioned. It is observed that visual attractivity phenomenon belonging to interior space characteristics has the least average value, in other words, the significance level of interior space visuality is less important according to other characteristics, for instance the encouragement phenomenon of the interior space for children development. As a matter of the fact, it is seen that the encouragement for the development for this characteristic is the most important phenomenon with a 3.9 value. Another sample for Table 3 is the flashiness of the environmental objects with a 2.7 average value, and this is a phenomenon less significant than the others in this section. When we talk about this characteristic, the most significant phenomenon is for them to be made of natural/healthy material and to be a shiny and enlightened space.

The study addresses all physical characteristics making up the interior space in a preschool educational center, as 
the main titles and sub titles indicated in the table 3 . As it is clear in the table 3 as well, awareness of the mentioned characteristics in the institutions where the study was applied is rather high and vital. In the spatial formation of the selected institutions, rather consistent relationships are revealed between the applied educational model and physical characteristics. Thus, as it can be understood from the table 3 and data about all spaces, conciouss approaches and evaluation criteria are revealed of the parents who prefer Montessori preschool educational institutions, and of the institution owners, administrators and educators. On the other hand, based on the experiences of the institutions and developing educational opportunities, and targets, aims and principles considered in the foregoing, there are also applications displaying variesness within their own selves. This, in turn, is an inevitable result of parameters, which are special to the institution, the positions held, and socio-cultural parameters. Since different expectations and necessities bring along different applications.

\section{Conclusion}

The focus of this study criticizing all decision makers of the preschool interior environment expectations, preferences, necessities etc...where young people come to experience and comprehend the world around them where every aspect plays a crucial role within the Montessori education in the preschool interior setting. Due to the rapid changes, a so-called "instant-noodle" culture is reflected in almost every aspect of life. Early Childhood education is a universal activity among young children, but its nature varies across cultures in response to specific constraints and differential degrees of encouragement (Bagby, 2010; Wilbrandt, 2006; Köksal at al,2005; Temel, 2005).

Interior spaces in preschool institutions are the physical environments where children establish relationships the most intensely and in a high level, outside home. Overlap of the educational system and space set up is the main matter targeted in these spaces. It is understood that Montessori institutions among the 30 institutions investigated turn out to be the most modest in this sense. Preschool space arrangement directed for the space design in educational decisions aiming children's development are the main elements of space groups, associative space arrangement, inter space characteristics and furniture-equipment characteristics. Conceptual contents of these elements (education, institutional identity, culture, etc.) should be considered within the physical space set up. Moreover, there is a strong relationship between the students and the environment in these kindergartens. The environment is prepared according to children but not teachers. Children start to put forward their inclinations not noticed up until then in such an environment. Thus, children display important development for becoming a new personality owing to their presence in an environment cleared from obstacles. The study was set up within this framework. The survey has revealed rather consistent results from the survey, observation and interview outcomes. In the inter space studied under the main titles, namely Properties of Interiors, General Spatial Standards of Day Care Centre, Atmospheric Properties Floor, Wall, Furnishings etc...), Furniture and Education Equipment, and sub titles questioning concepts that are intended to be included in the children's development by means of space in preschool Montessori Model, namely children based education, universality and permanent space feeding were found rather significant by respondents in the survey and that took place among the selection criteria.

\section{References}

Bagby, J. H. and Jones, N. (2010). "Montessori Education and Practice: A Review of the Literature, 2007-2009"Montessori Life, Vol. 22, No. 1, pp. 44-48.

Bozdayi, A. M. 1988 Children In The Physical Environment An Aproach To Design For

Children A Day Care Center Proposal in Beytepe. Ankara: Master Theses, Faculty of Architecture, METU.

Çanakçıoğlu, N.G., (2012) Çocukta Mekân Algısının Gelişimi ve Mekânsal imge Zenginliği Bakımından Malzemenin Önemi, Mimarlıkta Malzeme Sayı: 2. pp. 1-8.

Day C., \& Midbjer A. (2007). Environment and children: Passive lessons from the everyday environment (1st ed.). Amsterdam, NL and London, UK: Architectural Press.

Demiriz S., Karadağ A., Ulutaş İ. (2003). Okulöncesi Eğitim Kurumlarında Eğitim Ortamı ve Donanım. Ankara: Anı Yayıncılık.

Dudek M. (2000). Kindergarten Architecture: Space for the Imagination. Second edition. London, UK: Spon Press.

Dudek M. (2001). Building for Young Children: A Practical Guide to Planning, Designing and Building the Perfect Space. London, UK: National Early Years Network.

Dyck J. A. (2002), The Built Environment's Effect on Learning: Applying Current Research, The Architectural Partnership, pp. 1-10.

Flores M. A. (2004). The Impact of School Culture and Leadership on New Teachers Learning in the Workplacelnt. J. Leadership in Educationvolume:7.

Gür Ö. Ş, Zorlu T. (2002). Çocuk Mekânları. İstanbul: Yem Yayınları.

Korkmaz, E. (2006). Montessori metodu eğitimde bir alternatif. Ankara: Algı Yayın.

Köksal A. ve Oğuz, V. (2005). Millî Eğitim Bakanlığı 2002 23-72 aylık çocuklar için okulöncesi eğitim programı ile Montessori yaklaşımı arasındaki benzerlikler. XIV. UlusalEğitim Bilimleri Kongresi. Pamukkale Üniversitesi Eğitim Fakültesi. 28-30 Eylül 2005. Denizli. Bildiri Kitabı. pp. 913-919.

M.E.B. (2013) Okulöncesi Eğitim Genel Müdürlüğü Kreş Anaokulu ve Anasınıfi Programı, M.E.B. Basımevi, İstanbul, pp.25-44.

Montessori M. (1964). The Montessori method. Massachusetts: Robert Bentley Inc.

Poyraz, H., Dere H. (2001), Okul öncesi Eğitimin Illke ve Yöntem- 
leri. Ankara: Anı Yayıncılık.

Rapoport A. (2000), "Culture, Architecture and Design”, Locke Science Publishing Company, Inc.

Şener E. (2001), Okul Öncesi Çocuk Eğitim Merkezleri için Değişebilir/Dönüşebilir/Esnek Bir "Fiziksel Çevre Modeli", Doktora Tezi, ITÜ Mimarlık Fakültesi

Temel Z.F. (2005). Okul öncesi eğitimde yeni yaklaşımlar. Bilim ve Aklın Aydınlığında Eğitim Dergisi, 6(62).

Weinstein C.S., \& David T.G. (Eds.) (1987). Spaces for Children: The
Built Environment and Child Development. New York: Plenum. Wilbrandt Ç.E. (2006).“Okul Öncesi Eğitimde Montessori YakIaşımı”, Kök Yay. pp. 84.

Yaran P. (2009). Reproduction and Differentiation Strategies of Upper-Middle Class Group in Ankara, Theses of Master, Graduate School of Social Sciences, METU.

Yin R. K. (2003). Analyzing case study evidence. In study research: Design and methods (pp. 109-140). California: Sage Publications. 